Acta Scientifica Naturalis

Former Annual of Konstantin Preslavsky University - Chemistry, Physics, Biology, Geography Journal homepage: asn.shu.bg

Received:12.2018

Accepted:01.2019

\title{
Phytochemical Studies Antibacterial and Antioxidant Activities of Aerial Parts of Ferula lutea (Poir.) Maire.
}

\author{
Ibtissem Boulacel ${ }^{1}$, Brahim Harkati ${ }^{2}$, Radia Ayad ${ }^{1}$, Ibrahim Demirtas ${ }^{3}$, Hocine Laouer ${ }^{4}$, Salah \\ Akkal $^{1}$ \\ ${ }^{1}$ Université de Constantine 1, unité de recherche molécules bioactives et analyse physico- \\ chimique et biologique, Département de chimie, faculté des sciences exactes, Algérie. \\ ${ }^{2}$ Laboratoire des Molécules Bioactives et Applications, Université Larbi Tébessi - Tébessa \\ ${ }^{3}$ University of Çankırı Karatekin, Faculty of Science, Department of Chemistry, Ballica \\ Campus, 18100 Çankırı /TURKEY. \\ ${ }^{4}$ Université Ferhat Abbas de Sétif 1, Laboratoire de Valorisation des Ressources Naturelles \\ Biologiques, Département de Biologie et d'écologie végétale, Algérie.
}

\begin{abstract}
The focus of this paper was to assess the phytochemical composition, the antioxidant and antibacterial activities of the crude extracts of the aerial parts of Ferula lutea. Four new compounds were isolated from this genus, and their structures were primarily established by extensive spectroscopic analysis including $1 D$ and $2 D$ spectroscopic techniques. Total phenolics and flavonoids containing in ethyl acetate (AcOEt) and n-butanol (n-BuOH) extracts were quantified [199.1-184.02 mg gallic acid equivalent / $\mathrm{g}$ of dry weight], flavonoids [70.24$65.95 \mathrm{mg}$ quercetin / g dry weight]. DDPH scavenging and phosphomolybdenum methods were used to evaluate in vitro antioxidant activity. The obtained results showed a significant antioxidant activity of the two aerial parts. Correlation analysis between the DPPH values and those for TAC indicates the possibility of the two models for evaluating antioxidants power from medicinal plants. Dichloromethane $\left(\mathrm{CH}_{2} \mathrm{Cl}_{2}\right)$, AcOEt and $n-\mathrm{BuOH}$ extracts were screened against two gram-negative [Escherichia coli (E.coli) and Pseudo aeruginosa (P.aer)] and two gram-positive [Staphylococcus aureus (S.aur) and Bacillus (Bacil.)] bacteria using disc diffusion method. The results indicate a good inhibition of $\mathrm{CH}_{2} \mathrm{Cl}_{2}$ and EtAct extracts on the growth of (Bacil. and E.coli). Furthermore n-but extract showed a significant inhibitory effect only against E.coli.
\end{abstract}

Keywords: Ferula lutea, phenolics, flavonoids, antioxidant, antibacterial. 


\section{sciendo}

\section{Introduction}

Commonly known, natural products from medicinal plants represent one of the most important raw materials used for treating various human diseases because of the supreme availability of chemical diversity. With multiple biological activities, many plants contain antioxidant activity which attracts the attention of several research teams for its role in the fight against numerous illness and numerous studies have identified compound within herbal plants that are effective antibiotics [1]. The genus Ferula (Umbellifereae) has around 170 species [2], mostly growing in arid regions of temperate eurasia, in canary islands, in north Africa and in central Asia [3]. However, Ferula species are reputed in folk medicine for the treatment of skin infections [4], diabetes, prevent convulsion and hysteria [5], rheumatism, arthritis, headache, dizziness and stomach pain [6]. In the framework of the valorization of the Algerian forest resources and to develop new products, we are interested in the present study by Ferula lutea, the selection of this plant was guided by its traditional use and also because only few studies were conducted on this plant.

\section{Materials and Methods \\ Plant material}

The aerial parts of Ferula lutea were collected during flowering stage from Setif region eastern of Algeria in May 2014 and were identified by Pr. H. Laouer from the department of biology and plant ecology (University of Setif 1, Algeria).A voucher specimen was deposited in the herbium of our laboratory (Chifa DZUMCAPPV00027).

\section{Preparation of plant extracts.}

$1 \mathrm{Kg}$ of dried aerial parts of F.lutea was immersed in methanolic solution (MeOH, $70 \%)$ at room temperature for 24 hours then extracted. The step was repeated for three times to extract the majority of the desired chemical components from the plant materials. The hydromethanolique extract was evaporated to dryness and the residue was dissolved in distilled water, filtered, and the filtrate was concentrated under vacuum with a rotary evaporator to give $255.81 \mathrm{~g}$ of methanolic extract. The residue was then extracted with $\mathrm{CH}_{2} \mathrm{Cl}_{2}$, EtOAc and $n$ $\mathrm{BuOH}$ successively in triplicate to give $6.8 \mathrm{~g}$ of $\mathrm{CH}_{2} \mathrm{Cl}_{2}, 2.9 \mathrm{~g}$ of EtOAc and $25 \mathrm{~g}$ of $n$-BuOH extracts.

\section{Isolation of compounds}

The $\mathrm{CH}_{2} \mathrm{Cl}_{2}$ extract (6.8g) was chromatographed over silica gel column chromatography (200 g, silica gel 60, Merck, 35-70 $\mu \mathrm{m}$ ), starting the elution with a mixture of hexane / dichloromethane (from 100:0 to 0:100), followed by a mixture of dichloromethane/ethyl acetate (from 100:0 to 0:100), and finally with ethyl acetate / methanol (from 100:0 to 50:50). The obtained elutes were monitored using TLC plates viewed under UV light (254 and $365 \mathrm{~nm}$ ) and by spraying $1 \%$ of vanillin solution, $2 \%$ of sulfuric acid/ethanol $\left(\mathrm{H}_{2} \mathrm{SO}_{4} / \mathrm{EtOH}\right)$ reagent followed by heating at $100{ }^{\circ} \mathrm{C}$. The fractions [20-23] eluted with 70/30 hexane/dichloromethane $(12 \mathrm{mg}$ ) showed one spot, which was purified with sephadex LH20 by analytical methanol to give $7 \mathrm{mg}$ of white crystals: Methyl meristate (1) (Figure 1). Combined fractions [41-55] eluted with 40/60 hexane/dichloromethane $(65 \mathrm{mg})$ provide a mixture of a spot and chlorophyll. After purification of this fraction by acetone, $23 \mathrm{mg}$ of white needles were obtained: Maltol (2). The fractions [107-109] eluted with 100\% ethyl acetate showed one spot, which was purified with sephadex LH20 by analytical methanol to give $(6 \mathrm{mg})$ white crystals: ß-sitostérol-3-O-ß-D-glucoside (3) (18 mg) and Spinasterol-3-O-ß-D-glucopyranoside (4) (5 mg) which was precipitated as an amorphous white powder from the AcOEt extract. 


\section{Determination of total phenolic content}

The total phenol content of the F.lutea extracts was measured spectrometrically according to the Folin Ciocalteu's method as described by Li et al [7]. dry extracts were solubilized with methanol to a final concentrations. A liquots of these samples $(0.3 \mathrm{ml})$ were mixed with $1.5 \mathrm{ml}$ of the Folin-ciocalteu reagent (diluted 10 times with distilled water) and 1.2 $\mathrm{ml}$ of an aquous Sodium carbonate solution (7.5\%) was added after $4 \mathrm{mn}$. Absorbance was read at $765 \mathrm{~nm}$ after 2 hours of incubation against a blank (solution with no extract added). Gallic acid was used to prepare a calibration curve and results are expressed in gallic equivalents (mg GA.E/g dry extraction).

\section{Determination of total flavonoid content}

The content in flavonoids was determined spectrophotometrically according to the $\mathrm{AlCl}_{3}$ method developed by Djeridane [8]. Dry extracts were solubilized with methanol to a final concentration of $(\mathrm{mg} / \mathrm{ml})$. A liquots of these simples $(1 \mathrm{ml})$ were mixed with an equal volume of $\mathrm{AlCl}_{3}$ solution (2\% in methanol). The mixture was vigorously shaken and the absorbance was read at $430 \mathrm{~nm}$ after $10 \mathrm{mn}$ of incubation at ambient temperature. Quercetin was used to prepare a calibration curve and results are expressed as Quercetin equivalent (mg Q.E/g dry extract).

\section{Antioxidant activity}

\section{Free Radical Scavenging DPPH Radical}

The antioxidant activity for the $F$. lutea extracts were evaluated according to the method described by Yan [9]. Equal volumes of the methanolic solution of 1,1-diphenyl 1.2picrylhydrazyl (DPPH, $0.2 \mathrm{mM}$ ) and of the extracts (at the various concentrations indicated) were mixed and kept at room temperature for $30 \mathrm{mn}$. The absorbance was denoted at $517 \mathrm{~nm}$, beside a methanol solvent as control solution.

$$
\text { The scavenging }=(\text { A control }- \text { A sample } / \text { A control }) \times 100
$$

where: A control is the absorbance at $517 \mathrm{~nm}$ of DPPH solution without addition of the extracts. A sample is the absorbance at $517 \mathrm{~nm}$ of extracts. Ascorbic acid was used as a reference standard. $\mathrm{IC}_{50}$ values (concentration of extract necessary to reduce by $50 \%$ of the initial quantity of DPPH).

\section{Total antioxidant capacity (TAC).}

Total antioxidant capacity (TAC) of $F$. lutea extracts were spectrophotometrically determined by the phosphomolybdenum assay using the method described by Pieto [10]. Briefly, $0.3 \mathrm{~mL}$ of methanolic extracts solutions $(2 \mathrm{mg} / \mathrm{mL})$ was mixed with $3 \mathrm{~mL}$ of phosphomolybdenum reagent $(0.6 \mathrm{M}$ sulphuric acid, $28 \mathrm{mM}$ sodium phosphate and $4 \mathrm{mM}$ ammonium molybdate) in capped tubes. Incubation was then carried out for $90 \mathrm{~min}$ in water bath at $95^{\circ} \mathrm{C}$. After cooling to room temperature; the absorbance of the solutions was measured using UV-visible spectrophotometer at $695 \mathrm{~nm}$ against a control solution $(0.3 \mathrm{~mL}$ methanol without extract). TAC results were expressed as ascorbic acid equivalents (mg A.A.E/g of dry sample). 


\section{Antimicrobial activity}

Microbial strains.

All clinical strains bacteria [Staphylococcus.aureus, Bacillus, Escherichia.coli, Pseudomonas. aeruginosa], were obtained from laboratory of bacteriology at Constantine University hospital (C.H.U).

\section{Inhibitory effect and data processing.}

The $\mathrm{CH}_{2} \mathrm{Cl}_{2}$, EtOAc and $n-\mathrm{BuOH}$ extracts of F.lutea were investigated for their antibacterial activity using disk diffusion method [11], where the bacterial strains were first cultured on Mueller-Hinton agar for 24 hours at $37^{\circ} \mathrm{C}$. A sterilized filter disk $(6 \mathrm{~mm}$ diameter from Whatman paper $\mathrm{N}^{\circ} 3$ ) was placed on the infusion agar seeded with bacteria and impregnated with $40 \mu \mathrm{l}$ of the extract suspended in ethanol $60 \%$, for all concentration $(2 \mathrm{mg} / \mathrm{ml}$, $1 \mathrm{mg} / \mathrm{ml}, 0.5 \mathrm{mg} / \mathrm{ml}, 0.25 \mathrm{mg} / \mathrm{ml})$. After that Petri dish were left at $4{ }^{\circ} \mathrm{C}$ for $1 \mathrm{~h}$, and then incubated at $37{ }^{\circ} \mathrm{C}$ for 24 hours. The diameters of inhibition zones were measured in millimeters and all tests were performed in triplicate. The antibacterial potential extracts were assessed in terms of inhibition zone of bacterial growth. The results of the antibacterial activity were expressed as means $\pm \mathrm{SD}$ and presented in tables 1-3. The control treatment (ethanol $60 \%$ ) had no inhibitory effect on any of the tested microorganisms.

\section{Results and Discussion}

\section{Identification of compounds}

Compound(1): $\mathrm{C}_{15} \mathrm{H}_{30} \mathrm{O}_{2}$, white crystals, $\mathrm{M}=242.40 \mathrm{~g} / \mathrm{mol} .{ }^{1} \mathrm{H}-\mathrm{NMR}\left(600 \mathrm{MHz}, \mathrm{CDCl}_{3}, \delta / \mathrm{ppm}\right.$, $\mathrm{J} / \mathrm{Hz}) \quad 0.87(t, 3 \mathrm{H}, J=7.2, \mathrm{CH}-3), 1.25(20 \mathrm{H}, s, \mathrm{H}-4, \mathrm{H}-13), 1.63(2 \mathrm{H}, m, \mathrm{H}-3), 2.35(2 \mathrm{H}, t, J=7.2$, $\mathrm{H}-2), 3.67(3 \mathrm{H}, m, 3 \mathrm{H}) .{ }^{13} \mathrm{C}-\mathrm{NMR}\left(150 \mathrm{MHz}, \mathrm{CDCl}_{3}, \delta / \mathrm{ppm}\right):(\mathrm{C}-1) 179.28$, (C-2) 34.10, (C-3) 24.94, (C-4 to C-11) 29.1 4-29.66, (C-12) 31.9, (C-13) 22.67, (C-14) 14.09, (C-15) 51.39. It was identified as Methyl meristate [12].

Compound (2): $\mathrm{C}_{6} \mathrm{H}_{6} \mathrm{O}_{3}$, colorless needles, $\mathrm{M}=126 \mathrm{~g} / \mathrm{mol}$. ${ }^{1} \mathrm{H}-\mathrm{NMR}\left(250 \mathrm{MHz}, \mathrm{CDCl}_{3}, \delta / \mathrm{ppm}\right.$, $\mathrm{J} / \mathrm{Hz}): 2.39(3 \mathrm{H}, S, \mathrm{CH}-3), 5.32(1 \mathrm{H}, s, \mathrm{OH}), 6.46(1 \mathrm{H}, d, J=5.5, \mathrm{H}-5), 7.74(1 \mathrm{H}, d J=5.5, \mathrm{H}-6)$. ${ }^{13} \mathrm{C}-\mathrm{NMR}\left(75 \mathrm{MHz}, \mathrm{CDCl}_{3}, \delta / \mathrm{ppm}\right)$ : (C-2) 154.30, (C-3) 149.53, (C-4) 173.23, (C-5) 113.27, (C-6) 143.33, (C-7) 14.44. It was identified as Maltol [13].

Compound (3): $\mathrm{C}_{35} \mathrm{H}_{60} \mathrm{O}_{6}$, white amorphous powder, $\mathrm{M}=576.859 \mathrm{~g} / \mathrm{mol} .{ }^{1} \mathrm{H}-\mathrm{NMR}(600 \mathrm{MHz}$, DMSO-d6, $\delta / \mathrm{ppm}, \mathrm{J} / \mathrm{Hz}): \quad 0.65(3 \mathrm{H}, s, \mathrm{H}-18), 0.79(9 \mathrm{H}, s, \mathrm{H}-26, \mathrm{H}-27$ and $\mathrm{H}-29), 0.90(1 \mathrm{H}, d$, $j=5.4, \mathrm{H}-21), \quad 0.95(3 \mathrm{H}, \mathrm{s}, \mathrm{H}-19), 2.00(1 \mathrm{H}, m, \mathrm{H}-20), 3.02\left(1 \mathrm{H}, m, \mathrm{H}^{\prime}-4\right), 3.07\left(1 \mathrm{H}, m, \mathrm{H}^{\prime}-3\right)$, 3.12(1H, m, H'-5), 3.39(1H, m, H'-6a), 3.58(1H, m, H-3), 3.65(1H, m, H'-6b), 4.22(1H, d, $\left.j=7.2, \mathrm{H}^{\prime}-1\right)$, , 5.33(1H, s, H-6). ${ }^{13} \mathrm{C}-\mathrm{NMR}$, (150 MHz,DMSO-d6): (C-1) 37.28, (C-2) 29.71, (C3) 77.36, (C-4) 40.48, (C-5) 140.89, (C-6) 121.65, (C-7) 31.87, (C-8) 31.82, (C-9) 50.05, (C10) 36.66, (C-11) 21.04, (C-12) 38.75, (C-13) 42.30, (C-14) 56.62, (C-15) 24.31, (C-16) 28.24, (C-17) 55.87, (C-18) 12.12, (C-19) 19.55, (C-20) 35.93, (C-21) 19.07, (C-22) 33.79, (C-23) 25.88, (C-24) 45.58, (C-25) 29.15, (C-26) 19.39, (C-27) 20.17, (C-28) 23.05, (C-29) 12.24, (C1') 101.21, (C-2') 73.91, (C-3') 77.20, (C-4') 70.55, (C-5') 77.18, (C-6') 61.54. It was identified as $\beta$-sitosterol -3-O- $\beta$-D-glucoside [14].

Compound (4): $\mathrm{C}_{35} \mathrm{H}_{58} \mathrm{O}_{6}$, white amorphous powder, $\mathrm{M}=574.423 \mathrm{~g} / \mathrm{mol}$. ${ }^{1} \mathrm{H}-\mathrm{NMR} \quad(600 \mathrm{MHz}$ DMSO-d6, $\delta / \mathrm{ppm}, \mathrm{J} / \mathrm{Hz}$ ): 0.50(3H, s,H-18), 0.72(3H, s, H-19), 0.76(6H, s, H-26 and H-29), $0.81\left(3 \mathrm{H}, d, J=6, \mathrm{H}_{27}\right), 0.98(3 \mathrm{H}, d, J=6.6, \mathrm{H}-21), 1.93(1 \mathrm{H}, d, j=11.4, \mathrm{H}-5), 3.39(1 \mathrm{H}, m, \mathrm{H}-6 \mathrm{a})$, 
3.53(1H, $m, \mathrm{H}-3), 3.62\left(1 \mathrm{H}, m, \mathrm{H}^{\prime}-6 \mathrm{~b}\right), 4.2\left(1 \mathrm{H}, d, J=7.8, \mathrm{H}-1^{\prime}\right), 5.02(1 \mathrm{H}, d d, J=9,15, \mathrm{H}-23)$, 5.10(1H, $s, \mathrm{H}-7), 5.14(1 \mathrm{H}, d d, J=9,15, \mathrm{H}-22),{ }^{13} \mathrm{C}-\mathrm{NMR}$ (DMSO-d6, $\left.150 \mathrm{MHz}, \delta / \mathrm{ppm}\right)$ : (C1) 37.00, (C-2) 29.54, (C-3) 76.75, (C-4) 34.40, (C-5) 40.52, (C-6) 29.67, (C-7) 117.66, (C-8) 139.47, (C-9) 49.11, (C-10) 34.40, (C-11) 21.70, (C-12) 39.70, (C-13) 43.28, (C-14) 54.93, (C15) 22.99, (C-16) 28.57, (C-17) 55.66, (C-18) 12.32, (C-19) 13.24, (C-20) 40.74, (C-21) 21.45, (C-22) 138.37, (C-23) 129.43, (C-24) 51.05, (C-25) 31.77, (C-26) 19.30, (C-27) 21.42, (C-28) 25.33, (C-29) 12.57, (C-1') 101.30, (C-2') 73.94, (C-3') 77.20, (C-4') 70.55, (C-5') 77.15, (C-6') 61.57. It was identified as Spinasterol 3-O-ß3-D- glucopyranoside [15].

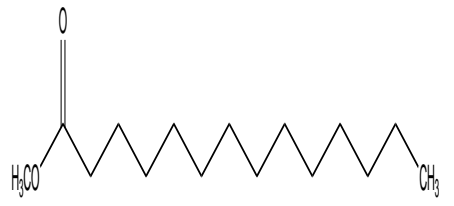

Methyl meristate

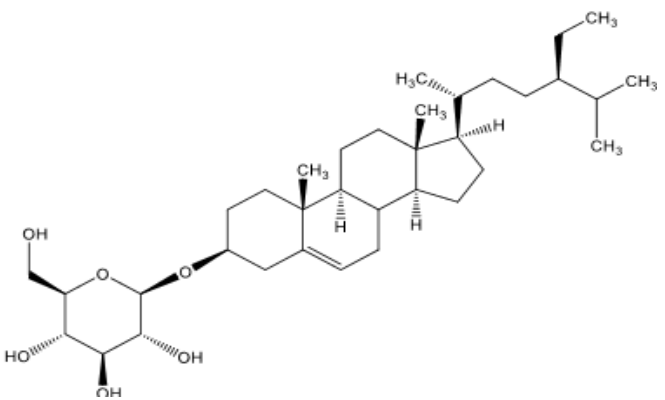

B-sitosterol -3-O $O$ - $\beta$-D-glucoside<smiles>Cc1occc(=O)c1O</smiles>

Maltol

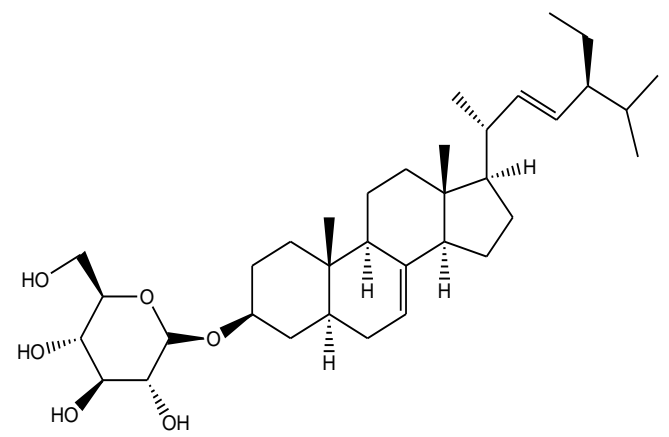

Spinasterol 3-O-ß-D- glucopyranoside

Fig.1: Structures of compounds isolated from aerial parts of Ferula lutea.

\section{Total phenolic and flavonoid contents.}

Total phenolic and flavonoid contents of ethyl acetate and butanolic extracts of aerial parts of Ferula lutea are illustrated in table 1.

Table 1. Total phenolic and flavonoid contents of the AcOEt and $\mathrm{BuOH}$ extracts of aerial parts of Ferula lutea.

\begin{tabular}{|c|c|c|c|}
\hline Plant & Extract & Phenol contents & Flavonoid contents $^{(\mathrm{b})}$ \\
\hline \multirow{2}{*}{ Ferula lutea } & AcOEt & $199.10 \pm 2.05$ & $70.24 \pm 0.87$ \\
\cline { 2 - 4 } & $\mathrm{BuOH}$ & $184.02 \pm 2.84$ & $65.95 \pm 1.25$ \\
\hline
\end{tabular}

a: expressed as $\mathrm{mg}$ Gallic acid /g of extract, b: expressed as $\mathrm{mg}$ quercetin /g of extract.

The results obtained in this study (table 1) showed a significant level of phenolic compounds in the two studied extracts, where we found remarkable values for both extracts; $199.10 \pm 2.05$ and $184.02 \pm 2.84 \mathrm{mg} \mathrm{GAE} / \mathrm{g}$ of extracts (successively AcOEt extract and ButOH extract). The flavonoid content of the AcOEt extract was the highest with $70.24 \pm 0.87$ $\mathrm{mg}$ QE/g extract while the $\mathrm{n}$ - butanol extract had $65.95 \pm 1.25 \mathrm{mg} \mathrm{QE} / \mathrm{g}$ extract. the phenolics and flavonoids content of aerial parts of Ferula lutea has not been reported in the literature, but 
we find the study of Manssour Zenati (F.lutea, flowers) showed that the total phenolics were $52.3 \pm 0.4$ and $40.7 \pm 0.2 \mathrm{mg}$ GAE/g of dry weight and the total flavonoids were 14.7 and $12.4 \pm$ $0.1 \mathrm{mg} \mathrm{QE} / \mathrm{g}$ of dry weight (successively AcOEt extract and ButOH extract) [16].

\section{Free Radical Scavenging DPPH Radical}

The antioxidant activity of the extracts was investigated using DPPH and TAC is presented in tables II and III. By the DPPH test, the best result was obtained with $n$-BuOH extract $\mathrm{IC}_{50}=0.12 \mathrm{mg} / \mathrm{ml}$ ) followed by the ethyl acetate extract $\mathrm{IC}_{50}=0.13 \mathrm{mg} / \mathrm{ml}$. the two extracts have good radical scavenging activity in comparison with positive control Ascorbic acid (Vit C, $\mathrm{IC}_{50}=0.04 \mathrm{mg} / \mathrm{ml}$ ). Total antioxidant capacity of extracts was determined as $181.45 \pm 0.25$ for EtOAc extract and $175.78 \pm 2.51$ for $n$-BuOH extract. In addition, the antioxidant capacities obtained from the DPPH scavenging assay were in good accordance with those obtained from TAC assay, which implies that the antioxidants in this plant were able to scavenge free radicals and reduce oxidants where we find n-butanol extract possessed high radical scavenging activity, but ethyl acetate extract possessed high oxidant reducing activity. Presence of this phytochemicals in aerial parts of $F$. lutea provides some scientific evidence for the traditional usage of this plant.

The antioxidant activity (DPPH, TAC) aerial parts of $F$. lutea extracts, has not been cited in the literature before[16]. Only, F.lutea flowers was evaluated for antioxidant activity with DPPH assay giving an $\mathrm{IC}_{50}=12.8 \pm 1.3 \mu \mathrm{g} / \mathrm{ml}$ and $\mathrm{IC}_{50}=26.0 \pm 1.8 \mu \mathrm{g} / \mathrm{ml}$ and with ABTS assay giving an $\mathrm{IC}_{50}=184.0 \pm 7 \mu \mathrm{g} / \mathrm{ml}$ and $\mathrm{IC}_{50}=300 \pm 5 \mu \mathrm{g} / \mathrm{ml}$ successively for AcOEt and $\mathrm{n}-\mathrm{BuOH}$ extracts.

Table 2. DPPH scavenging activities of EtOAc and $\mathrm{BuOH}$ extracts of aerial parts of Ferula lutea. Ascorbic Acid were used as positive control

\begin{tabular}{|l|l|c|c|}
\hline & Linear Equation & $\mathrm{IC}_{50}$ & APR \\
\hline Ascorbic acid & $\mathrm{Y}=1506 \mathrm{x}-10.20\left(\mathrm{R}^{2}=0.995\right)$ & 0.04 & 25 \\
\hline EtOAc & $\mathrm{Y}=325 \mathrm{x}+7.090\left(\mathrm{R}^{2}=0.972\right)$ & 0.13 & 7.69 \\
\hline BuOH & $\mathrm{Y}=347.9 \mathrm{x}+7.506\left(\mathrm{R}^{2}=0.974\right)$ & 0.12 & 8.33 \\
\hline
\end{tabular}

All analyses are the mean of triplicate measurement \pm standard deviation.

Table 3. Total activity capacity of the AcOEt and ButOH extracts of aerial parts

Ferula lutea.

\begin{tabular}{|l|l|l|}
\hline Extract & EtOAc & $\mathrm{BuOH}$ \\
\hline Total antioxidant capacity & $181.45 \pm 0.25$ & $175.78 \pm 2.51$ \\
\hline
\end{tabular}

All analyses are the mean of triplicate measurement \pm standard deviation.

\section{Antibacterial activity}

The diffusion test was applied to 4 Gram positive and Gram negative microorganism. The control treatment (ethanol $60 \%$ ) had no inhibitory effect on any of the tested microorganism and the results of these tests are illustrated in tables I, V and VI. 
Table 4. Antibacterial activity of the extract $\mathrm{CH}_{2} \mathrm{Cl}_{2}$.

\begin{tabular}{|l|l|l|l|l|c|}
\hline & \multicolumn{3}{|c|}{$\mathrm{CH}_{2} \mathrm{Cl}_{2}$} & Ethanol 60\% \\
\hline Microorganismes & $0.25 \mathrm{mg} / \mathrm{ml}$ & $0.5 \mathrm{mg} / \mathrm{ml}$ & $1 \mathrm{mg} / \mathrm{ml}$ & $2 \mathrm{mg} / \mathrm{ml}$ & - \\
\hline S.aureus & $06.0 \pm 0.0$ & $06.0 \pm 0.0$ & $06.0 \pm 0.0$ & $06.0 \pm 0.0$ & - \\
\hline Bacillus & $17.00 \pm 1.7$ & $17.00 \pm 1.7$ & $17.00 \pm 1.7$ & $20.00 \pm 0.9$ & - \\
\hline E.coli & $14.33 \pm 1.2$ & $14.33 \pm 1.2$ & $14.33 \pm 1.2$ & $15.00 \pm 1.0$ & - \\
\hline p.aeruginosa & $07.33 \pm 1.2$ & $07.33 \pm 1.2$ & $07.33 \pm 1.2$ & $06.67 \pm 1.2$ & - \\
\hline
\end{tabular}

Table 5. Antibacterial activity of the extract EtOAc.

\begin{tabular}{|l|l|l|l|l|c|}
\hline & \multicolumn{3}{|c|}{ EtOAc } & Ethanol 60\% \\
\hline Microorganismes & $0.25 \mathrm{mg} / \mathrm{ml}$ & $0.5 \mathrm{mg} / \mathrm{ml}$ & $1 \mathrm{mg} / \mathrm{ml}$ & $2 \mathrm{mg} / \mathrm{ml}$ & - \\
\hline S.aureus & $06.0 \pm 0.0$ & $06.0 \pm 0.0$ & $06.0 \pm 0.0$ & $06.0 \pm 0.0$ & - \\
\hline Bacillus & $15.00 \pm 1.7$ & $15.00 \pm 1.0$ & $16.00 \pm 0.0$ & $17.33 \pm 1.2$ & - \\
\hline E.coli & $12.00 \pm 1.7$ & $14.33 \pm 1.2$ & $16.66 \pm 1.2$ & $17.00 \pm 1.2$ & - \\
\hline p.aeruginosa & $06.0 \pm 0.0$ & $06.0 \pm 0.0$ & $06.0 \pm 0.0$ & $06.0 \pm 0.0$ & - \\
\hline
\end{tabular}

Table 6. Antibacterial activity of the extract $n-\mathrm{BuOH}$

\begin{tabular}{|l|l|l|l|l|c|}
\hline & \multicolumn{3}{|c|}{ n-butanol } & Ethanol 60\% \\
\hline Microorganismes & $0.25 \mathrm{mg} / \mathrm{ml}$ & $0.5 \mathrm{mg} / \mathrm{ml}$ & $1 \mathrm{mg} / \mathrm{ml}$ & $2 \mathrm{mg} / \mathrm{ml}$ & - \\
\hline S.aureus & $06.00 \pm 0.0$ & $06.00 \pm 0.0$ & $06.00 \pm 0.0$ & $06.00 \pm 0.0$ & - \\
\hline Bacillus & $06.00 \pm 0.0$ & $06.00 \pm 0.0$ & $06.00 \pm 0.0$ & $06.00 \pm 0.0$ & - \\
\hline E. coli & $16.66 \pm 0.6$ & $17.66 \pm 0.6$ & $18.70 \pm 1.2$ & $18.80 \pm 1.0$ & - \\
\hline p.aeruginosa & $07.00 \pm 0$ & $07.66 \pm 1.2$ & $07.00 \pm 0.0$ & $06.00 \pm 0.0$ & - \\
\hline
\end{tabular}

The antibacterial activity of F.lutea aerial parts extracts against microorganism was examined in the present study. The microorganisms $S$. aureus, which is already known to be multi-resistant to drugs and $P$. aeruginosa, which is also resistant to different antibiotics, were also resistant to the plant extracts tested. On the other hand, $n$-butanol extract has no activity against Bacillus. The n-BuOH, EtOAc and $\mathrm{CH}_{2} \mathrm{Cl}_{2}$ extracts showed a good activity against $E$. coli with higher concentration of $2 \mathrm{mg} / \mathrm{ml}$ and presented an inhibition zone $18.80 \pm 1.0,17.00$ \pm 1.2 and $15.00 \pm 1.0 \mathrm{~mm}$, respectively (tables $\mathrm{I}, \mathrm{V}$ and $\mathrm{VI}$ ). $\mathrm{CH}_{2} \mathrm{Cl}_{2}$ extract exhibited the best activity against Bacillus and showed an inhibition zone $20.00 \pm 0.9 \mathrm{~mm}$ with high concentration of $2 \mathrm{mg} / \mathrm{ml}$, the EtOAc extract presented also a good activity with $17.33 \pm 1.2 \mathrm{~mm}$ at the last concentration (table V). Among the tested extracts, the $\mathrm{CH}_{2} \mathrm{Cl}_{2}$ and EtOAc were more effective than $\mathrm{n}-\mathrm{BuOH}$ extract.

The n-butanol extract exhibited more interesting antimicrobial activities than the ethyl acetate extract (Ferula lutea, flowers) [16]. .

\section{Conclusion}

The results obtained in this work find four compounds were isolated the first time from the extracts obtained from the aerial parts of Ferula lutea, the structures of the isolated compounds were identified by extensive spectroscopic analysis including 1D and 2D spectroscopic techniques. The compounds are: Methyl meristate (1), Maltol (2), ß-sitosterol-3O-ß-D-glucoside (3), spinasterol-3-O-ß-D-glucopyranoside (4). 
The present study demonstrated that total phenolic and total flavonoid content varied between the tested extracts. In addition, the DPPH radical scavenging activity and TAC assay were found to be significantly correlated with the amount of TPC and TFC. In this work, it is confirmed that the plant extracts tested not only as antioxidant but also as antibacterial, when we find the antibacterial activity of the dichloromethane and acetate extracts was especially very strong against Bacillus and butanol extract was very strong against E.coli.

The present results therefore offer a scientific basis for traditional use of Ferula lutea.

\section{Acknowledgements.}

We are thankful to the Algerian Minister of Higher Education and Scientific Research for providing a research grant.

\section{References}

[1]. Okpekon, T.; Yolou, S.; Gleye, C.; Roblot, F.; Loiseau, P.; Bories, C.; Grellier, F.; Frappier, F.; Laurens, A.; Hocquemiller, R., Antiparasitic activities of medicinal plants used in Ivory Coast, Journal of Ethnopharmacology, 2014, 90, 91-97.

[2]. Downie, S.R.; Watson, M.F.; Spalik, K.; Katrz-Downie.; D.S., Molecular systematic of old world 2. Apioideae (Apiaceae): Relationships among some members of tribe Peucedaneae sensu lato, the placement of several island-endemic species, \& resolution within the apioid superclade, Can. J. Bot., 2007, 8, 506-528.

[3]. Drude, O.; Engler, A., Die Nuturlichen Pflansenfamilien (In German); Ed.; Wilhelm Engelmann: Leipzig, Germany. 1898, 3, 288-232.

[4]. Appendino, G; Spagliardi, P; Cravotto, G; Pocock, V; Milligan, S ., Daucane phytoestrogens: Astructure-activity study, J. Nat. Prod., 2002, 65, 1612-1615.

[5]. Boulos, L; Algonac., Medicinal Plants of North Africa; ML. Reference Publications Inc: Alyonae, MI, USA, 1983.

[6].Tamemoto, K. Y; Takaishi, B; Chen, K; Kawazoe, H; Shibata, T; Higuti, G; Honda, M; Ito, Y; Takeda, O. K; Kodzhimatov. O., Sesquiterpenoid from the fruits of Ferula kuhistanica and antibacterial activity of the constituents of F; kuhistanica, Phytochemistry. 2001, 58 (5), 763767.

[7]. Li, H. B; Cheng, K; Wong, C. C; Fan, K. W; Chen, F ; Jiang. Y., Evaluation of antioxidant capacity and total phenolic content of different fractions of selected microalgae, Food Chemistry, 2007, 102, 771-776.

[8]. Djeridane, A; Yous, M; Nadjemi, B; Boutassouna, D; Stocker, P. Vidal, N., Antioxidant activity of some Algerian medicinal plants extracts containing phenolic compounds, Food Chem., 2006, 97, 654-660.

[9].Yan, G; Jil, L; Luo ,Y; Hu, Y., Antioxidant activities of extracts and fractions from Eupatorium lindleyanum DC, Molecules, 2011, 16, 5998.

[10]. Prieto, P; Pineda, M; Aguilar, M., Spectrophotometric quantification of antioxydant capacity through the formation of a phosphomolybdenum complexe : specific application to the determination of vitamine E, Analytical Biochemistry, 1999, 269 (2), 337-341. 
[11]. Sivasothy, Y; Sulaiman, S. F; Ooi. K .L; Ibrahim, H; Awang, K., Antioxidant and antibacterial activities of flavonoids and curcuminoids from Zingiber spectabile Griff, Food Control, 2013, 30, 714.

[12]. Ann-chee, Y; Kok-gan, C; Yeun-mun, C., Isolation and identification of metabolites from the Gram-negative proteobacteria of Burkholderia cenocepacia and Serratia morcescens, Sains Malaysiana, 2016, 45(7), 10073-1077.

[13]. Samejo, M. Q; Ndukwe, G. I; Burdi, D. K; Bhanger, M. I; Khan, K.M., Isolation and crystal structure of maltol from Abeis Pindrow, Journal of Medicinal plantsrecheach, 1999, $3,55-60$.

[14]. Mofiz Uddin Khan, N.M; Sagar Houssain, M.d., Scopoletin and ß-sitistéol glucoside from roots of Ipomoea digitata, Journal of Pharmacognosy and Phytochemistry, 2015, 4, 0507.

[15]. Fahee. A; Keng. C.W; Ibrahim. E; Mohammad. Z.A; Hasnah. O., Evaluation of Biological Activities of Extracts and Chemical constituents of Mimusops Elengi, Tropical Journal of pharmaceutical research, 2013, 12 (4), 591-596.

[16]. Luximon-Ramma, A; Bahorun, T; Soobrattee, A. M; Aruoma, O.I., Antioxidant activities of phenolic, proanthocyanodin and flavonoid components in extracts of acacia fistula, J. Agr. Food Chem., 2005, 50, 5042-5047.

[16]. Mansour, Z; Hichen, B. J; Sylvie, C; Jlloul, B., Chemical composition, biological and cytotoxic activities of plant extracts and compounds isolated from Ferula lutea, Molecules, 2014, 19, 2733-2747 